\title{
APLIKASI MATERIAL GEOSINTETIK PADA KONSTRUKSI TIMBUNAN DI ATAS TIANG (PILED EMBANKMENT)
}

\author{
Tommy Adam ${ }^{1}$ dan Andryan Suhendra ${ }^{2}$ \\ ${ }^{I}$ Program Studi Sarjana Teknik Sipil, Universitas Tarumanagara, Jl Letjen S. Parman 1 Jakarta \\ Email: tommyadam1996@gmail.com \\ ${ }^{2}$ Program Studi Sarjana Teknik Sipil, Universitas Tarumanagara, Jl Letjen S. Parman 1 Jakarta \\ Email: andryansuhendra@yahoo.com
}

\begin{abstract}
ABSTRAK
Timbunan di atas tanah lunak merupakan tantangan bagi insinyur geoteknik karena karakteristik tanah yang tidak diinginkan. Perkuatan geosintetik dengan dukungan tiang adalah salah satu cara yang bisa menyelesaikan karakteristik tanah yang tidak diinginkan ini. Skripsi ini akan membandingkan kuat tarik geosintetik dengan menggunakan metode BS 8006 dengan metode elemen hingga dua dimensi dan bagaimana geosintetik mempengaruhi timbunan. Skripsi ini membahas mengenai perbedaan antara perhitungan kuat tarik geosintetik dengan metode BS 8006 dengan metode elemen hingga karena metode perhitungan BS 8006 tidak memperhitungakan tanah dasar dalam memperhitungkan kuat tarik geosintetik. Skripsi ini juga membahas mengenai peningkatan nilai faktor keamanan sebesar $20 \%$ yang disebabkan oleh pemasangan geosintetik pada dasar timbunan.
\end{abstract}

Kata kunci: timbunan di atas tiang, plaxis, geosintetik, faktor keamanan

\section{PENDAHULUAN}

Tanah lunak merupakan salah satu permasalahan yang dialami pada berbagai konstruksi seperti bangunan, timbunan, dan lain sebagainya. Tanah lunak ini dapat menyebabkan kegagalan pada saat konstruksi, juga dapat menyebabkan penurunan yang sangat besar. Dalam penanganannya, dapat dilakukan dua perlakuan terhadap tanah lunak yaitu perbaikan dan perkuatan tanah lunak. Perbaikan dapat dilakukan dengan mengeluarkan air pada rongga tanah lalu dipadatkan agar tanah memadat. Perkerasan dapat dilakukan dengan memberikan perkerasan tiang, geosintetik, dan lain sebagainya.

Piled embankment merupakan salah satu meted perkerasan tanah lunak dengan menggunakan tiang pancang/bor. Setelah melakukan pemancangan terhadap tiang, agar transfer beban dapat dipindahkan dengan baik, maka diberikan pile cap untuk seluruh tiang. namun penggunaan pile cap beton memerlukan biaya yang cukup besar untuk pembelian besi dan beton. Maka penggunaan slab beton dapat digantikan dengan geosintetik.

Menurut Zheng et al (2009), kombinasi antara geosintetik dengan tiang dapat menurunkan penurunan yang tidak rata yang kadang terjadi di dasar timbunan apabila tidak diberi perkuatan. Geosintetik merupakan material buatan manusia yang dibuat untuk memudahkan pekerjaan manusia. Geosintetik dapat menggantikan fungsi slab beton pada tiang pancang untuk mentransfer gaya-gaya diatasnya ke tiang lalu ke tanah. Selain berfungsi untuk mentransfer beban geosintetik juga dapat berfungsi untuk meningkatkan stabilitas tanah, mencegah penurunan yang tidak merata dan untuk memberikan perkerasan pada dasar timbunan.

\section{DASAR TEORI}

\section{Piled embankment}

Piled embankment merupakan gabungan dari beberapa tiang yang digunakan untuk menahan timbunan dan beban diatasnya. Pada umumnya penggunaan piled embankment ini menggunakan pelat beton sebagai pile cap tiang kelompok. Namun penggunaan pelat beton dapat digantikan dengan menggunakan geosintetik. 


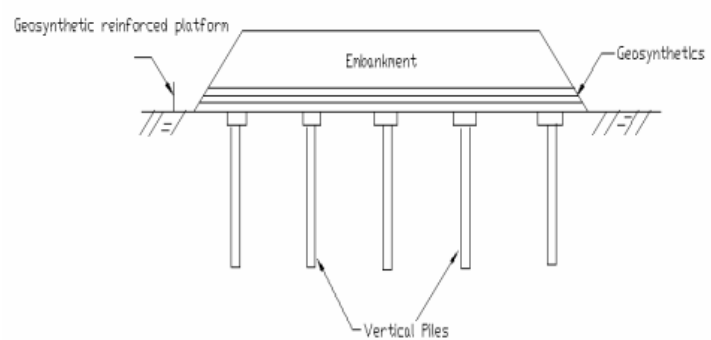

Piled embankment with a geogrid reinforced platform

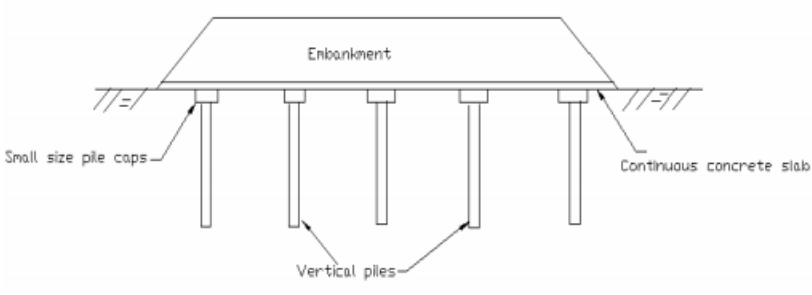

Piled embankment with a continuous concrete slab

Gambar 1 Piled embankment menggunakan pelat beton

Gambar 2 Piled embankment menggunakan geosintetik

\section{Metode perhitungan BS 8006}

Dalam perhitungan, beban yang digunakan adalah beban yang sudah didistribusi. Metode yang digunakan sangat konservatif. Rumus beban distribusi berbeda tergantung dari dimensi dan jarak antar tiang. Sebelum menghitung tegangan total pada perkerasan, perlu dihitung beban total pada dasar timbunan. Beban total pada dasar timbunan dapat dihitung dengan menggunakan rumus berikut.

$$
\begin{gathered}
\sigma_{V}^{s}=f_{f \sigma} \cdot \gamma \cdot H+f_{q} \cdot w_{s} \\
p_{c}^{r}=\sigma_{V}^{s}\left(\frac{C_{c^{*}} \cdot}{H}\right)^{2}
\end{gathered}
$$

Untuk nilai $C_{e}$ dapat dihitung menggunakan rumus :

$$
\begin{array}{ll}
\text { Untuk end-bearing piles } & C_{c}=1.95 \times \frac{H}{\sigma}-0.18 \\
\text { Untuk friction piles } & C_{c}=1.5 \cdot \frac{H}{\sigma}-0.07
\end{array}
$$

Untuk $H>1.4(s-a)$

$$
W_{T}=\frac{1.4 \cdot s \cdot f_{f s} \times \gamma \cdot(s-a)}{s^{2}-a^{2}} x\left(s^{2}-a^{2} \cdot\left(\frac{p_{c}^{t}}{\sigma_{V}^{t}}\right)\right)
$$

Untuk $0.7(s-a)<H<1.4(s-a)$

$$
W_{T}=\frac{s \cdot\left(f_{f s} \cdot \gamma \cdot H+f_{q} \cdot w_{s}\right)}{s^{2}-a^{2}} \cdot\left(s^{2}-a^{2}\left(\frac{p_{c}^{t}}{\sigma_{D}^{t}}\right)\right)
$$

Tetapi, apabila $\frac{g^{2}}{a^{2}} \leq \frac{p_{c}}{\sigma_{V}}$, maka $W_{T}=0$

Keterangan :

$W_{T} \quad$ : beban total pada perkerasan

s : jarak antar tiang

a $\quad$ : ukuran pile cap

$w_{g} \quad$ : distribusi pembebanan tambahan

$p_{e}^{f} \quad$ : tegangan vertikal pada pile cap

$\sigma_{D}^{*} \quad$ : tegangan vertikal pada dasar timbunan

$f_{f s} \quad$ : faktor parsial pada berat unit tanah

$f_{q} \quad$ : faktor parsial untuk beban eksternal 
$y \quad$ : massa jenis tanah

H : tinggi timbunan tanah

$C_{e} \quad$ : koefisien lengkung

Setelah memperoleh nilai beban total pada dasar timbunan, dapat dihitung faktor reduksi tegangan dan tegangan yang terjadi pada dasar timbunan. Faktor reduksi tegangan dan tegangan yang terjadi pada dasar timbunan dapat dihitung menggunakan rumus berikut.

Untuk $0.7(s-a)<H<1.4(s-a)$

$$
S_{a D}=\frac{2 . s}{(s+a)\left(s^{2}-a^{2}\right)} \cdot\left(s^{2}-a^{2}\left(\frac{p_{c}}{y \cdot H}\right)\right)
$$

Untuk $H>1.4(s-a)$ ( full arching )

$$
\begin{gathered}
S_{a D}=\frac{2.8 \cdot s}{(s+a)^{2} \cdot H} \cdot\left(s^{2}-a^{2}\left(\frac{p_{c}}{\gamma \cdot H}\right)\right) \\
T_{r p}=\frac{W_{T}(s-a)}{2 a} \sqrt{1+\frac{1}{6 \varepsilon}}
\end{gathered}
$$

Keterangan :

$S_{a D} \quad$ : faktor reduksi tegangan

$T_{r p} \quad$ : tegangan pada perkerasan

$\varepsilon \quad$ : regangan pada perkerasan

Setelah menghitung tegangan pada perkerasan berdasarkan regangan maksimum yang diijinkan pada perkerasan, perlu dilakukan tegangan pada perkerasan untuk menahan gaya horizontal yang bekerja pada dasar timbunan. Tegangan ini disebabkan oleh tekanan tanah aktif dari timbunan. Tegangan untuk menahan gaya horizontal dapat dicari menggunakan rumus berikut.

$$
T_{d s}=0.5 \cdot K_{a} \cdot\left(f_{f s} \cdot \gamma \cdot H+2 \cdot f_{q} \cdot w_{s}\right) \cdot H
$$

Keterangan :

$T_{d s} \quad$ : tegangan untuk menahan gaya horizontal

$K_{\square} \quad$ : koefisien tekanan tanah aktif

$: \tan ^{2}\left(45-\frac{9}{2}\right)$

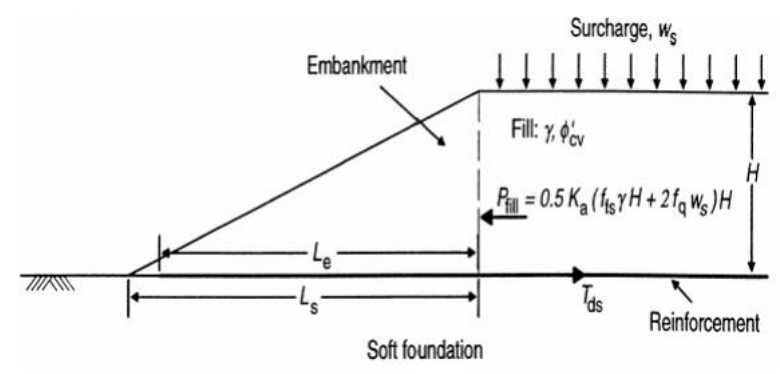

Gambar 3 Stabilitas geser lateral antara timbunan dengan perkerasan 


\section{Program plaxis}

Program plaxis merupakan program analisa geoteknik dengan menggunakan metode elemen hingga (finite element method) dua dimensi yang digunakan untuk merencanakan pondasi, menganalisis deformasi, stabilitas pada tanah, menghitung tegangan-tegangan yang terjadi pada timbunan dan lain sebagainya. Metode elemen hingga merupakan metode yang dipakai secara luas untuk menyelesaikan masalah-masalah rekayasa struktural berbasis komputer. Untuk melakukan permodelan pada program plaxis, diperlukan beberapa parameter tanah dalam program ini.

\section{Kohesi}

Kohesi merupakan gaya tarik menarik antara partikel sejenis. Nilai kohesi dapat berbeda-beda sesuai dengan jenis tanah itu sendiri. Penentuan kohesi dapat diperoleh melalui permeability test pada tes laboratorium atau bisa juga dengan menggunakan metode USCS.

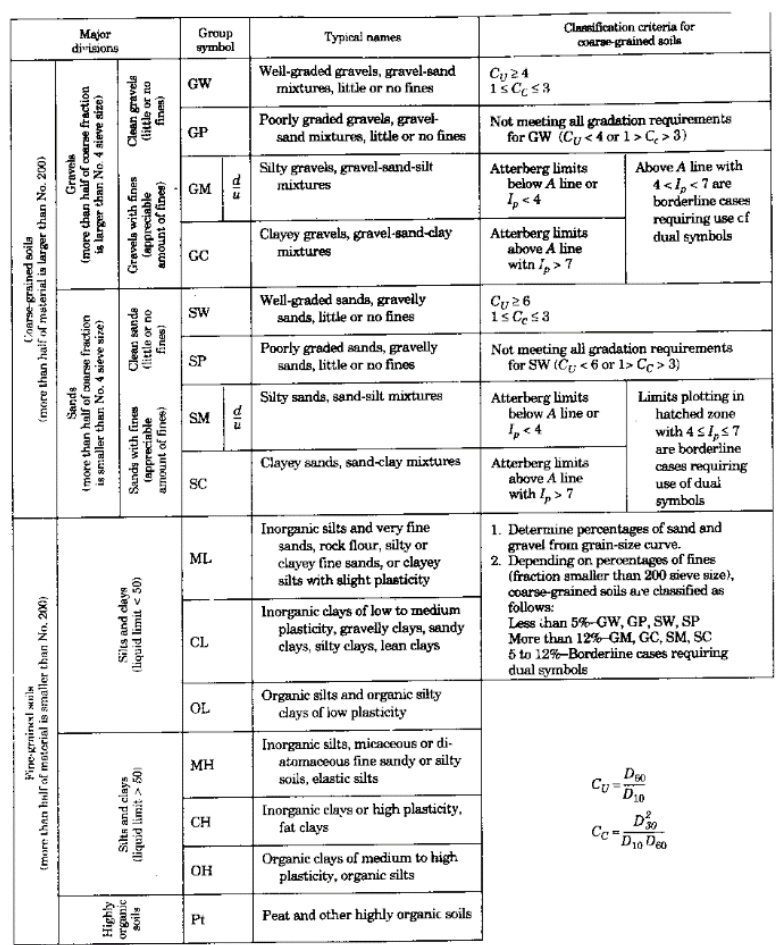

Gambar 4 Klasifikasi tanah dengan metode USCS (Terzaghi \& Peck, 1997)

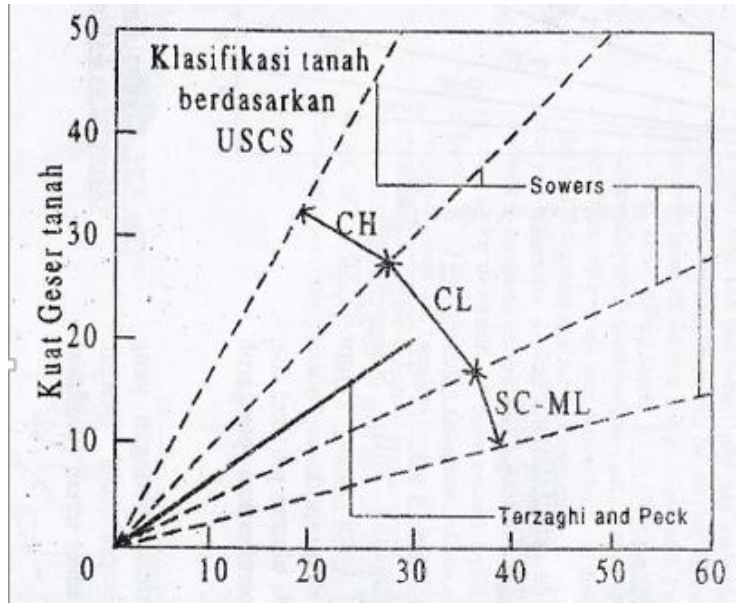

Gambar 5 Perkiraan hubungan N-SPT dengan nilai kuat geser tanah (Terzaghi \& Peck, 1997) 
Jurnal Mitra Teknik Sipil

Vol. 1, No. 1, Agustus 2018: hlm 231-240

\section{Modulus elastisitas}

Modulus Elastisitas merupakan nilai yang mengukur kemampuan suatu bahan untuk menahan deformasi elastis ketika bahan tersebut menerima suatu beban. Penentuan modulus elastisitas pada tiang dapat ditentukan menggunakan rumus berikut.

$$
E_{p}=4700 x \sqrt{f^{\prime} c}
$$

Keterangan :

$E_{p} \quad:$ moduus elastisitas

$f^{t} c \quad$ : mutu beton tiang

Nilai modulus elastisitas pada tanah berbeda tergantung pada jenis tanah, nilai N-SPT atau CPT. Menurut Budhu (2007), nilai modulus elastisitas pada tanah dapat dicari dengan menggunakan rumus sesuai dengan jenis tanah.

Tabel 1 Persamaan modulus elastisitas untuk berbagai jenis tanah (Budhu M, 2000)

\begin{tabular}{|c|c|c|}
\hline Soil & SPT & CPT \\
\hline \multirow[t]{3}{*}{ Sand (normally consolidated) } & $E S=500(N+15)$ & $E s=2$ to $4 \mathrm{qc}$ \\
\hline & $E s=(15000$ to 22000$) \ln N$ & $\mathrm{Es}^{\dagger}=\left(1+\mathrm{Dr}^{2}\right) \mathrm{qc}$ \\
\hline & $E s \S=(35000$ to 50000$) \log N$ & \\
\hline Sand (saturated) & $E s=250(N+15)$ & \\
\hline \multirow[t]{2}{*}{ Sand (overconsolidated) } & Est $=18000+750 \mathrm{~N}$ & $\mathrm{Es}=6$ to $30 \mathrm{qc}$ \\
\hline & $E_{S(O C R)}=E_{S(n c)}(O C R)^{1 / 2}$ & \\
\hline \multirow[t]{3}{*}{ Gravelly sand and gravel } & $E s=1200(N+6)$ & \\
\hline & $E s=600(N+6)$ & \\
\hline & $E s=600(N+6)+2000$ & \\
\hline Clayey Sand & $E s=320(N+15)$ & $E s=3$ to $6 q c$ \\
\hline Silty Sand & $E s=300(N+6)$ & $E s=1$ to $2 q c$ \\
\hline \multirow[t]{2}{*}{ Soft Clay } & - & $E s=3$ to $8 q c$ \\
\hline & Using the undrained shear strength Su in & units of Su \\
\hline \multirow[t]{3}{*}{ Clay } & $\mid p>30$ or organic & $\mathrm{Es}=100$ to $500 \mathrm{Su}$ \\
\hline & Ip $<30$ or stiff & $E s=500$ to $1500 \mathrm{Su}$ \\
\hline & $E_{S(O C R)}=E_{S(n c)}(O C R)$ & \\
\hline
\end{tabular}

\section{Sudut geser dalam}

Sudut geser dalam merupakan sudut yang terbentuk dari hubungan antara tegangan normal dengan tegangan geser di dalam material tanah atau batuan. Penentuan nilai sudut geser dalam ini biasanya dicari menggunakan triaxial test. Namun menurut Dunham (1962), nilai sudut geser tanah berpasir dapat dihitung menggunakan rumus berikut.

Untuk tanah berpasir berbentuk bulat dengan gradasi seragam,

$$
\Phi=\sqrt{12 N+15}
$$

Untuk butiran pasir bersegi-segi dengan gradiasi tidak seragam,

$$
\Phi=\sqrt{12 N+50}
$$

Butiran pasir bersegi dengan gradiasi seragam

$$
\Phi=0.3 N+27
$$

Keterangan :

$\Phi \quad$ : sudut geser dalam

$\mathrm{N} \quad$ : nilai N-SPT

\section{Poisson ratio}

Poisson ratio merupakan konstanta elastisitas yang dimiliki oleh semua material. Konstanta tersebut merupakan perbandingan antara deformasi lateral dengan deformasi aksial pada suatu material. Nilai poisson ratio berbeda-beda sesuai dengan jenis tanah. 
Tabel 2 Nilai poisson ratio berdasarkan jenis tanah (Budhu M, 2000)

\begin{tabular}{ll}
\hline Typa of soil & $\mu$ \\
\hline Clay, saturated & $0.4-0.5$ \\
Clay, unsaturated & $0.1-0.3$ \\
Sandy clay & $0.2-0.3$ \\
Silt & $0.3-0.35$ \\
Sand, gravelly sand & $0.1-1.00$ \\
$\quad$ commonly used & $0.3-0.4$ \\
Rock & $0.1-0.4$ (depends somewhat on type of rock) \\
Loess & $0.1-0.3$ \\
Ice & 0.36 \\
Concrete & 0.15 \\
Steel & 0.33 \\
\hline
\end{tabular}

\section{METODOLOGI PENELITIAN}

Pada penelitian ini, digunakan dua metode perhitungan untuk memperhitungkan kuat tarik geosintetik yang digunakan. Metode yang digunakan adalah metode perhitungan BS 8006 (2010) dengan metode elemen hingga (plaxis). Analisis ini digunakan untuk membandingkan perbedaan kuat tarik geosintetik dengan dua metode yang berbeda.

Setelah membandingkan, dilakukan simulasi kasus pelebaran jalan tol dengan menggunakan geosintetik pada piled embankment untuk meningkatkan nilai faktor keamanan pada timbunan tersebut. Simulasi dilakukan di metode elemen hingga dengan variasi jarak antar tiang, ukuran tiang dan kedalaman tiang untuk melihat pengaruh parameter tersebut terhadap nilai faktor keamanan.

\section{HASIL ANALISIS}

\section{Kondisi lapangan}

Pada analisis ini, diperoleh data tanah dasar yang memiliki karakteristik tanah sangat lunak hingga kedalaman $10 \mathrm{~m}$. Di atas tanah tersebut akan dibangun jalan tol dengan perkerasan yang sudah diperhitungkan. Lapisan tanah tersebut dianggap menjadi timbunan dan beban kepada tanah dibawahnya.
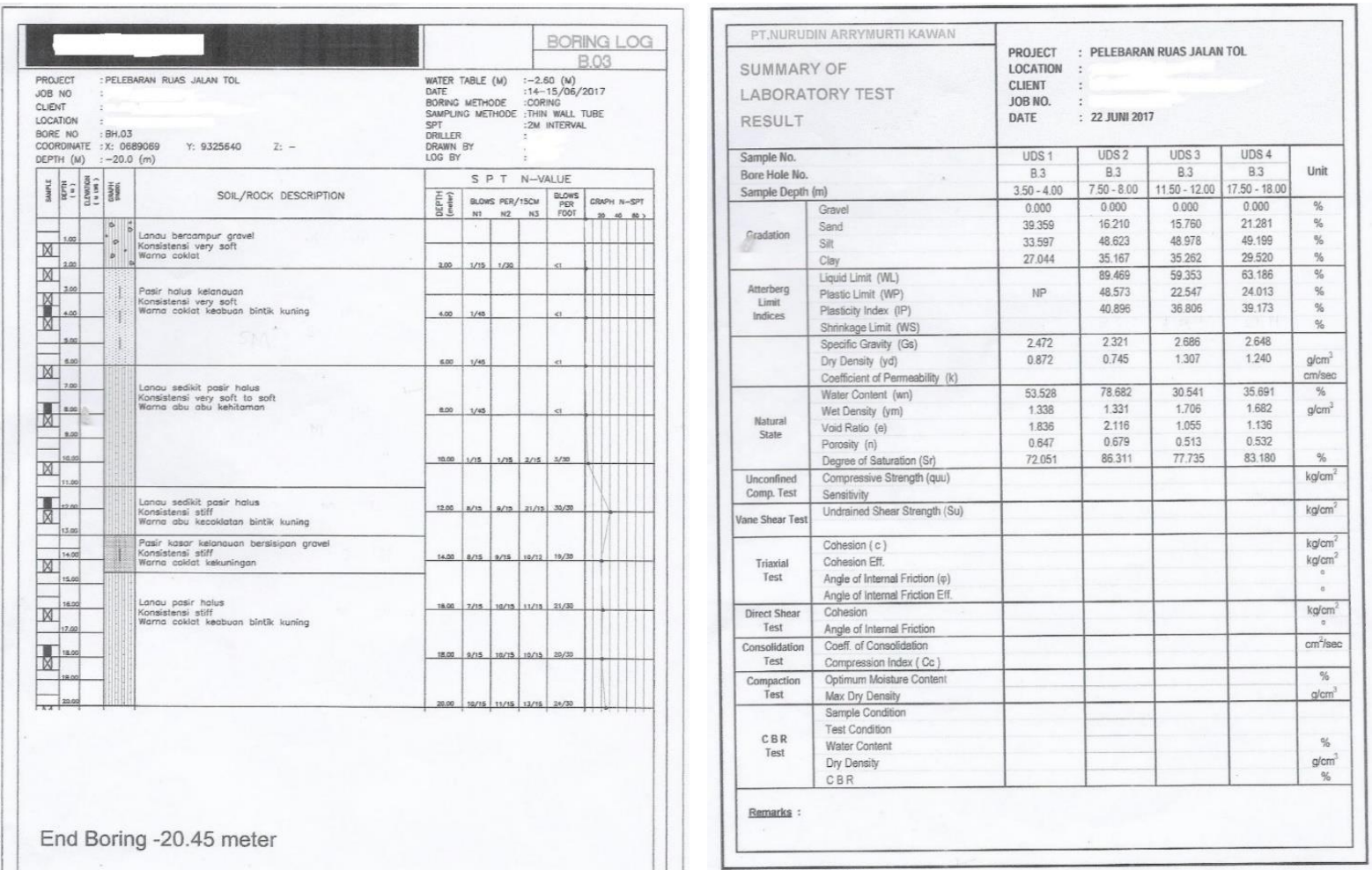

Gambar 6 Kondisi tanah dasar pada salah satu proyek pelebaran jalan tol di Jakarta 

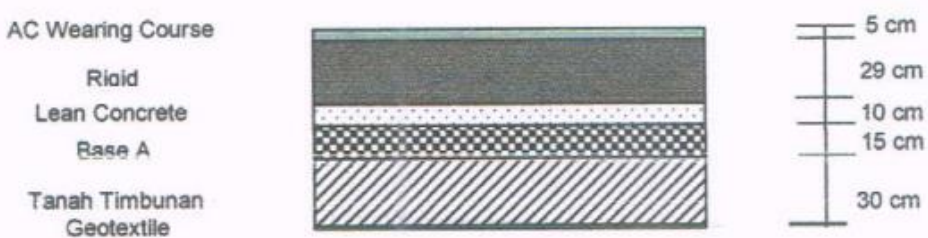

Gambar 7 Kondisi timbunan pada salah satu proyek pelebaran jalan tol di Jakarta

\section{Perbandingan perhitungan manual dengan metode elemen hingga}

Kuat tarik geosintetik diperhitungkan dengan variasi jarak antar tiang 0,5 m, $1 \mathrm{~m}$, dan 1,5 m, ukuran tiang $15 \mathrm{~cm} x$ $15 \mathrm{~cm}, 20 \mathrm{~cm}$ x $20 \mathrm{~cm}, 25 \mathrm{~cm}$ x $25 \mathrm{~cm}$ dan kedalaman tiang $12 \mathrm{~m}$ dan $15 \mathrm{~m}$. Setelah dilakukan perhitungan manual dan simulasi dengan program plaxis terhadap kondisi lapangan yang ada, diperoleh perbedaan nilai antara kedua metode tersebut.

Tabel 3 Perbandingan kuat tarik geosintetik antara perhitungan manual dengan program plaxis

\begin{tabular}{|c|c|c|c|c|}
\hline $\begin{array}{c}\text { Ukuran tiang } \\
(\mathrm{m})\end{array}$ & $\begin{array}{c}\text { Ukuran pile } \\
\text { cap }(\mathrm{m})\end{array}$ & $\begin{array}{c}\text { Jarak antar } \\
\text { tiang }(\mathrm{m})\end{array}$ & $\begin{array}{c}\text { Kuat tarik yang } \\
\text { digunakan }(\mathrm{kN} / \mathrm{m})\end{array}$ & $\begin{array}{c}\text { Kuat tarik geosintetik hasil } \\
\text { plaxis }(\mathrm{kN} / \mathrm{m})\end{array}$ \\
\hline \multirow{3}{*}{0,15} & \multirow{3}{*}{0,15} & 0,5 & 48 & 42,28 \\
\cline { 3 - 5 } & & 1 & 260 & 60,24 \\
\cline { 3 - 5 } & \multirow{3}{*}{0,2} & 1,5 & 580 & 80,03 \\
\hline \multirow{3}{*}{0,2} & 0,5 & 43 & 42,93 \\
\hline \multirow{3}{*}{0,25} & \multirow{3}{*}{0,25} & 1 & 187 & 61,55 \\
\cline { 3 - 5 } & & 0,5 & 425 & 80,07 \\
\cline { 3 - 5 } & & 1 & 40 & 43,82 \\
\cline { 3 - 5 } & & 1,5 & 142 & 60,27 \\
\hline
\end{tabular}

\section{Analisis nilai faktor keamanan}

Setelah membandingkan nilai kuat tarik geosintetik, dilakukan analisa nilai faktor keamanan terhadap proyek pelebaran jalan tol dengan menggunakan kombinasi antara tiang dengan material geosintetik. Analisa dilakukan dengan variasi jarak antar tiang, ukuran tiang dan kedalaman tiang seperti analisis sebelumnya. Analisis ini dilakukan dengan dua kondisi. Kondisi pertama adalah pada saat tanah pada jalan yang sudah ada diasumsikan sama dengan tanah pada pelebaran. Pada kondisi ini, pola kelongsoran yang terjadi tidak mengenai pelebaran sehingga menyebabkan analisis tidak akurat dan variasi parameter tiang tidak berpengaruh terhadap nilai faktor keamanan.

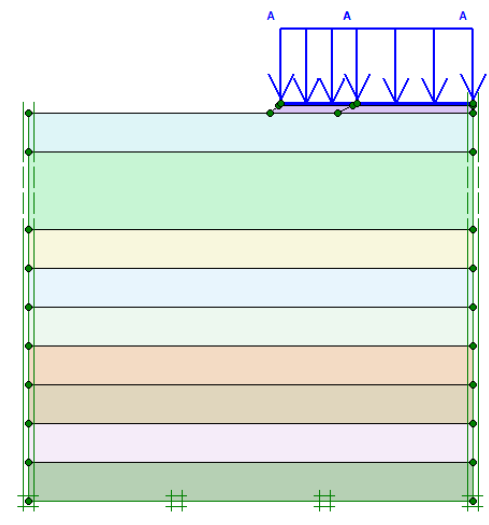

Gambar 8 Kondisi lapangan pada analisis pertama

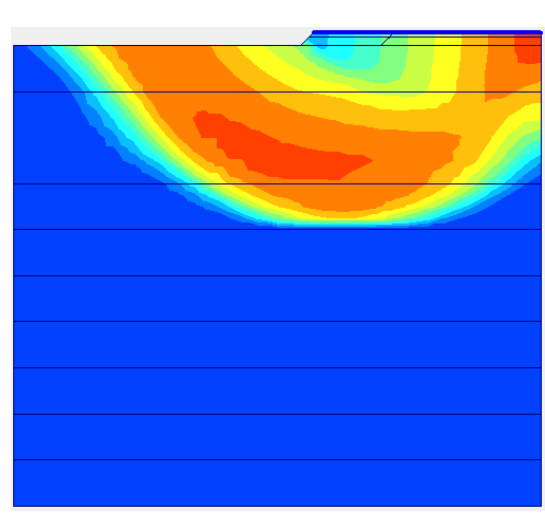

Gambar 9 Pola kelongsoran yang terjadi pada analisis pertama

Analisa kedua dilakukan dengan mengasumsikan tanah pada jalan yang sudah ada adalah tanah keras, sehingga pola kelongsoran berada pada pelebaran. Pada kondisi yang kedua ini, diperoleh nilai faktor keamanan tanpa perkerasan 3,6554 . 


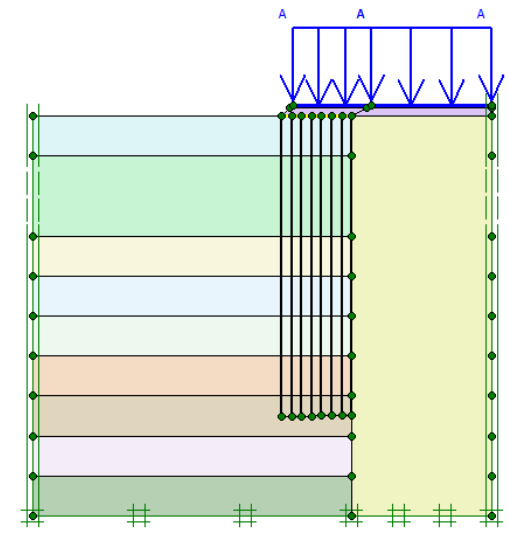

Gambar 10 Kondisi lapangan pada analisis kedua

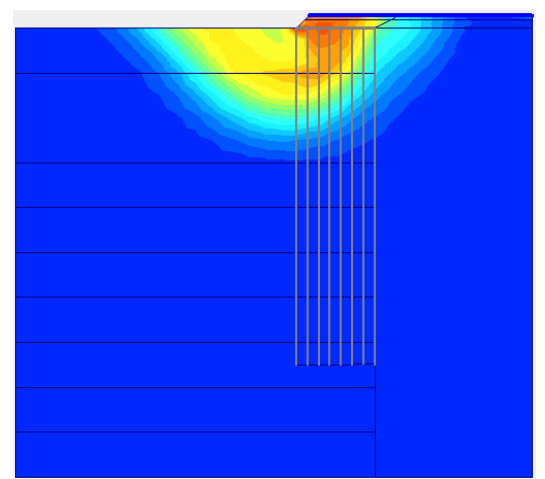

Gambar 11 Pola kelongsoran yang terjadi pada analisis kedua

Setelah diperoleh nilai faktor keamanan terhadap kondisi awal, diberikan perkerasan terhadap kondisi tersebut. perkerasan diberikan sesuai dengan variasi jarak antar tiang, ukuran tiang dan kedalaman tiang sesuai dengan analisis sebelumnya. Berdasarkan analisis ini, didapatkan material geosintetik dapat meningkatkan nilai faktor keamanan sebesar $20 \%$.

Tabel 4 Pengaruh geosintetik terhadap peningkatan nilai faktor keamanan pada tiang $12 \mathrm{~m}$ dan $15 \mathrm{~m}$

\begin{tabular}{|c|c|c|c|c|c|c|c|c|c|c|c|c|c|c|c|}
\hline No & \begin{tabular}{|c|} 
Ukuran \\
Tiang (m) \\
\end{tabular} & $\begin{array}{c}\text { Ukuran Pile } \\
\text { Cap (m) }\end{array}$ & $\begin{array}{c}\text { Jarak antar } \\
\text { tiang }(\mathrm{m})\end{array}$ & \begin{tabular}{|c|} 
Kuat tarik \\
geosintetik $(\mathrm{kN} / \mathrm{m})$
\end{tabular} & SF & Keterangan & \begin{tabular}{|c|} 
Pengaruh \\
Geosintetik (\%)
\end{tabular} & No & \begin{tabular}{|c|} 
Ukuran \\
Tiang (m) \\
\end{tabular} & $\begin{array}{c}\text { Ukuran Pile } \\
\text { Cap (m) }\end{array}$ & $\begin{array}{l}\text { Jarak antar } \\
\text { tiang }(\mathrm{m})\end{array}$ & \begin{tabular}{|c|} 
Kuat tarik \\
geosintetik $(\mathrm{kN} / \mathrm{m})$
\end{tabular} & SF & Keterangan & \begin{tabular}{|c|} 
Pengaruh \\
Geosintetik (\%)
\end{tabular} \\
\hline \multirow[t]{2}{*}{1} & 0,15 & 0,15 & 0,5 & 48 & 5,0866 & \begin{tabular}{|l|} 
Tanpa Geosintetik \\
\end{tabular} & \multirow{2}{*}{16,026} & \multirow{2}{*}{1} & 0,15 & 0,15 & 0,5 & 48 & 5,0864 & \begin{tabular}{|l|} 
Tanpa Geosintetik \\
\end{tabular} & \multirow{2}{*}{15,842} \\
\hline & & & & & 5,9018 & Dengan Geosintetik & & & & & & & 5,8922 & Dengan Geosintetik & \\
\hline \multirow{2}{*}{2} & 0,15 & 0,15 & 1 & 260 & 4,7421 & Tanpa Geosintetik & \multirow{2}{*}{18,840} & \multirow{2}{*}{2} & 0,15 & 0,15 & 1 & 260 & 4,7118 & \begin{tabular}{|l|} 
Tanpa Geosintetik \\
\end{tabular} & \multirow{2}{*}{20,169} \\
\hline & & & & & 5,6355 & Dengan Geosintetik & & & & & & & 5,6621 & Dengan Geosintetik & \\
\hline \multirow{2}{*}{3} & 0,15 & 0,15 & 1,5 & 580 & 4,4758 & Tanpa Geosintetik & \multirow{2}{*}{17,154} & \multirow{2}{*}{3} & 0,15 & 0,15 & 1,5 & 580 & 4,6933 & \begin{tabular}{|l|} 
Tanpa Geosintetik \\
\end{tabular} & \multirow{2}{*}{12,160} \\
\hline & & & & & 5,2436 & Dengan Geosintetik & & & & & & & 5,264 & Dengan Geosintetik & \\
\hline \multirow{2}{*}{4} & 0,2 & 0,2 & 0,5 & 43 & 5,1155 & \begin{tabular}{|l|} 
Tanpa Geosintetik \\
\end{tabular} & \multirow{2}{*}{15,433} & \multirow{2}{*}{4} & 0,2 & 0,2 & 0,5 & 43 & 5,1868 & \begin{tabular}{|l|} 
Tanpa Geosintetik \\
\end{tabular} & \multirow{2}{*}{13,571} \\
\hline & & & & & 5,905 & Dengan Geosintetik & & & & & & & 5,8907 & Dengan Geosintetik & \\
\hline \multirow{2}{*}{5} & 0,2 & 0,2 & 1 & 187 & 4,6614 & \begin{tabular}{|l|} 
Tanpa Geosintetik \\
\end{tabular} & \multirow{2}{*}{20,655} & \multirow{2}{*}{5} & 0,2 & 0,2 & 1 & 187 & 4,7655 & \begin{tabular}{|l|} 
Tanpa Geosintetik \\
\end{tabular} & \multirow{2}{*}{18,940} \\
\hline & & & & & 5,6242 & Dengan Geosintetik & & & & & & & 5,6681 & \begin{tabular}{|l|} 
Dengan Geosintetik \\
\end{tabular} & \\
\hline \multirow{2}{*}{6} & 0,2 & 0,2 & 1,5 & 425 & 4,5226 & \begin{tabular}{|l|l} 
Tanpa Geosintetik \\
\end{tabular} & \multirow{2}{*}{16,455} & \multirow{2}{*}{6} & 0,2 & 0,2 & 1,5 & 425 & 4,7075 & Tanpa Geosintetik & \multirow{2}{*}{10,745} \\
\hline & & & & & 5,2668 & Dengan Geosintetik & & & & & & & 5,2133 & \begin{tabular}{|l|} 
Dengan Geosintetik \\
\end{tabular} & \\
\hline \multirow{2}{*}{7} & 0,25 & 0,25 & 0,5 & 40 & 5,1069 & Tanpa Geosintetik & \multirow{2}{*}{15,597} & \multirow{2}{*}{7} & 0,25 & 0,25 & 0,5 & 40 & 5,0923 & Tanpa Geosintetik & \multirow{2}{*}{15,698} \\
\hline & & & & & 5,9034 & Dengan Geosintetik & & & & & & & 5,8917 & \begin{tabular}{|l|} 
Dengan Geosintetik \\
\end{tabular} & \\
\hline \multirow{2}{*}{8} & 0,25 & 0,25 & 1 & 142 & 4,765 & \begin{tabular}{|l|} 
Tanpa Geosintetik \\
\end{tabular} & \multirow{2}{*}{17,906} & \multirow{2}{*}{8} & 0,25 & 0,25 & 1 & 142 & 4,7784 & \begin{tabular}{|l|} 
Tanpa Geosintetik \\
\end{tabular} & \multirow{2}{*}{18,575} \\
\hline & & & & & 5,6182 & Dengan Geosintetik & & & & & & & 5,666 & Dengan Geosintetik & \\
\hline 9 & 0,25 & 0,25 & 1,5 & 328 & 4,4858 & \begin{tabular}{|l|} 
Tanpa Geosintetik \\
\end{tabular} & 16815 & 9 & 0,25 & 0,25 & 1,5 & 328 & 4,6263 & \begin{tabular}{|l|} 
Tanpa Geosintetik \\
\end{tabular} & 12969 \\
\hline & & & & & 5,2401 & Dengan Geosintetik & & & & & & & 5,2263 & Dengan Geosintetik & 12,969 \\
\hline
\end{tabular}

Setelah dilakukan analisis terhadap pengaruh geosintetik terhadap tiang, dilakukan analisis nilai faktor keamanan terhadap perubahan jarak antar tiang, ukuran tiang dan kedalaman tiang.

Tabel 5 Nilai faktor keamanan terhadap perubahan jarak antar tiang

\begin{tabular}{|c|c|c|c|c|}
\hline No & $\begin{array}{c}\text { Kedalaman } \\
\text { Tiang }(\mathrm{m})\end{array}$ & \begin{tabular}{|c|} 
Ukuran Tiang \\
$(\mathrm{m})$
\end{tabular} & $\begin{array}{l}\text { Jarak antar } \\
\text { tiang }(\mathrm{m})\end{array}$ & Safety Factor \\
\hline 1 & \multirow{9}{*}{12} & \multirow{3}{*}{0,15} & 0,5 & 5,9018 \\
\hline 2 & & & 1 & 5,6355 \\
\hline 3 & & & 1,5 & 5,2436 \\
\hline 4 & & \multirow{3}{*}{0,2} & 0,5 & 5,905 \\
\hline 5 & & & 1 & 5,6242 \\
\hline 6 & & & 1,5 & 5,2668 \\
\hline 7 & & \multirow{3}{*}{0,25} & 0,5 & 5,9034 \\
\hline 8 & & & 1 & 5,6182 \\
\hline 9 & & & 1,5 & 5,2401 \\
\hline 10 & \multirow{9}{*}{15} & \multirow{3}{*}{0,15} & 0,5 & 5,8922 \\
\hline 11 & & & 1 & 5,6621 \\
\hline 12 & & & 1,5 & 5,264 \\
\hline 13 & & \multirow{3}{*}{0,2} & 0,5 & 5,8907 \\
\hline 14 & & & 1 & 5,6681 \\
\hline 15 & & & 1,5 & 5,2133 \\
\hline 16 & & \multirow{3}{*}{0,25} & 0,5 & 5,8917 \\
\hline 17 & & & 1 & 5,666 \\
\hline 18 & & & 1,5 & 5,2263 \\
\hline
\end{tabular}

Tabel 6 Nilai faktor keamanan terhadap perubahan ukuran tiang

\begin{tabular}{|c|c|c|c|c|}
\hline No & $\begin{array}{c}\text { Kedalaman } \\
\text { Tiang }(\mathrm{m})\end{array}$ & $\begin{array}{c}\text { Ukuran Tiang } \\
(\mathrm{m})\end{array}$ & $\begin{array}{l}\text { Jarak antar } \\
\text { tiang }(\mathrm{m})\end{array}$ & Safety Factor \\
\hline 1 & \multirow{9}{*}{12} & 0,15 & \multirow{3}{*}{0,5} & 5,9018 \\
\hline 2 & & 0,2 & & 5,905 \\
\hline 3 & & 0,25 & & 5,9034 \\
\hline 4 & & 0,15 & \multirow{3}{*}{1} & 5,6355 \\
\hline 5 & & 0,2 & & 5,6242 \\
\hline 6 & & 0,25 & & 5,6182 \\
\hline 7 & & 0,15 & \multirow{3}{*}{1,5} & 5,2436 \\
\hline 8 & & 0,2 & & 5,2668 \\
\hline 9 & & 0,25 & & 5,2401 \\
\hline 10 & \multirow{9}{*}{15} & 0,15 & \multirow{3}{*}{0,5} & 5,8922 \\
\hline 11 & & 0,2 & & 5,8907 \\
\hline 12 & & 0,25 & & 5,8917 \\
\hline 13 & & 0,15 & \multirow{3}{*}{1} & 5,6621 \\
\hline 14 & & 0,2 & & 5,6681 \\
\hline 15 & & 0,25 & & 5,666 \\
\hline 16 & & 0,15 & \multirow{3}{*}{1,5} & 5,264 \\
\hline 17 & & 0,2 & & 5,2133 \\
\hline 18 & & 0,25 & & 5,2263 \\
\hline
\end{tabular}


Tabel 7 Nilai faktor keamanan terhadap perubahan kedalaman tiang

\begin{tabular}{|c|c|c|c|c|}
\hline No & $\begin{array}{c}\text { Kedalaman } \\
\text { Tiang }(\mathrm{m})\end{array}$ & \begin{tabular}{|c} 
Ukuran Tiang \\
$(\mathrm{m})$
\end{tabular} & $\begin{array}{c}\text { Jarak antar } \\
\text { tiang }(\mathrm{m})\end{array}$ & Safety Factor \\
\hline 1 & 12 & \multirow{6}{*}{0,15} & \multirow{2}{*}{0,5} & 5,9018 \\
\hline 2 & 15 & & & 5,8922 \\
\hline 3 & 12 & & \multirow{2}{*}{1} & 5,6355 \\
\hline 4 & 15 & & & 5,6621 \\
\hline 5 & 12 & & \multirow{2}{*}{1,5} & 5,2436 \\
\hline 6 & 15 & & & 5,264 \\
\hline 7 & 12 & \multirow{6}{*}{0,2} & \multirow{2}{*}{0,5} & 5,905 \\
\hline 8 & 15 & & & 5,8907 \\
\hline 9 & 12 & & \multirow{2}{*}{1} & 5,6242 \\
\hline 10 & 15 & & & 5,6681 \\
\hline 11 & 12 & & \multirow{2}{*}{1,5} & 5,2668 \\
\hline 12 & 15 & & & 5,2133 \\
\hline 13 & 12 & \multirow{6}{*}{0,25} & \multirow{2}{*}{0,5} & 5,9034 \\
\hline 14 & 15 & & & 5,8917 \\
\hline 15 & 12 & & \multirow{2}{*}{1} & 5,6182 \\
\hline 16 & 15 & & & 5,666 \\
\hline 17 & 12 & & \multirow{2}{*}{1,5} & 5,2401 \\
\hline 18 & 15 & & & 5,2263 \\
\hline
\end{tabular}

Berdasarkan penelitian yang dilakukan, dapat dilihat perubahan nilai faktor keamanan hanya berpengaruh terhadap jarak antar tiang. Nilai faktor keamanan hanya berpengaruh $0,16-1 \%$ terhadap perubahan ukuran tiang dan kedalaman tiang.

\section{KESIMPULAN}

Berdasarkan analisis yang dilakukan terhadap berbagai simulasi yang ada, dapat disimpulkan sebagai berikut.

1. Kuat tarik geosintetik dengan metode perhitungan BS 8006 (2010) dengan metode elemen hingga (plaxis) memiliki perbedaan yang cukup besar. Perbedaan ini akan semakin besar apabila jarak antar tiang semakin besar

2. Material geosintetik meningkatkan nilai faktor keamanan pada timbunan, namun peningkatannya dipengaruhi oleh efektivitas dari geosintetik. Pada percobaan yang dilakukan, geosintetik dapat meningkatkan nilai faktor keamanan sebesar $20 \%$

3. Semakin besar jarak antar tiang, nilai faktor keamanan akan semakin kecil. Perbedaan nilai faktor keamanan ini sebesar $4-8 \%$ apabila dilakukan penelitian dengan perbedaan jarak antar tiang $0,5 \mathrm{~m}$

4. Perubahan nilai faktor keamanan terhadap perubahan ukuran dan kedalaman tiang diperoleh sebesar 0,16 $1 \%$. Hal ini menunjukkan bahwa berdasarkan percobaan yang dilakukan, perubahan ukuran dan kedalaman tiang tidak mempengaruhi nilai faktor keamanan

5. Berdasarkan analisis yang dilakukan, apabila digunakan perkuatan dengan tiang persegi berukuran $15 \mathrm{~cm} \mathrm{x}$ $15 \mathrm{~cm}$, dengan jarak antar tiang 0,5 m dan kedalaman $1,5 \mathrm{~m}$ dan geosintetik dengan kuat tarik $48 \mathrm{kN} / \mathrm{m}$, maka beban yang bekerja pada timbunan dapat dipikul dengan baik.

\section{SARAN}

Berdasarkan analisis yang telah dilakukan, disarankan melakukan analisis penggunaan geosintetik terhadap piled embankment dengan metode perhitungan yang lain termasuk analisis terhadap penurunan tanah pada konstruksi timbunan.

\section{DAFTAR PUSTAKA}

Ariyarathne, P , Liyanapathirana, D.S. 2015. Review of existing design method for geosynthetic-reinforced piled supported embankments. Elsevier B.V:The Japanese Geotechnical Society.

Boogert, T.J.M den. 2011. Piled Embankments with Geosynthetic Reinforcement. Thesis. Delft : Delft University of Technology.

Brinkgreve, R.B.J,ed. 2002. PLAXIS 2D-Version 8, Netherland: A.A.Barkema Publishers.

British Standard. 2010. Code of practice for strengthened/reinforced soil and other fills.London : BSI Standards Publication.

Budhu, M. 2000. Soil Mechanic and Foundations. New York: John Wiley and Sons. 
Das,B.M. 1994. Mekanika Tanah (Prinsip-prinsip Rekayasa Geoteknis) Jilid I. Jakarta: Erlangga.

Direktorat Jenderal Bina Marga. 2009.PEDOMAN Konstruksi dan Bangunan. Jakarta: Departemen Pekerjaan Umum, Direktorat Jenderal Bina Marga, Direktorat Bina Teknik.

Gangakhedkar, R. 2004. Geosynthetic Reinforced Pile Supported Embankments. Thesis. Florida: University of Florida.

Peck, R.B , Terzaghi, K. 1967. Soil Mechanics in Engineering Practice. New York : John Wiley and Sons. 